\title{
Improving Motivation English Learning By Implementation Savi Approach at PGSD Students
}

\author{
Rohana $^{1}$, Syamsuddin ${ }^{2}$, Fatun Fatimah Azahrah ${ }^{3}$ \\ \{rohana@unm.ac.id ${ }^{1}$, rhnsyamsuddin@gmail.com ${ }^{2}$, fatunfatimah.2606@gmail.com ${ }^{3}$ \} \\ Fakultas Ilmu Pendidikan UNM Makassar
}

\begin{abstract}
This research aims at finding the Elementary Teacher Education Program students', the motivation of the student in learning English by the implementation of SAVI approach (Semiotic, Auditory, Visual, and Intellectual) in English Learning. The research employed experiment design. There were 26 students participated in this research. The instrument used in this research questionnaires, observations, and test. The research report illustrations the student motivation toward English learning by implementation SAVI approach. The analyzed the data show that motivation the students in control classes average $79,62 \%$ in medium category and in experiment class average $88,38 \%$ in high category it has increase motivation in learning English, from the data analysis it was obtain t table $(2,336>2,008) \mathrm{t}$ account with $\alpha=5 \%$ and $\mathrm{df}=50$, Therefore, there was significant influence of using Somatic Auditory Visual Intellectual (SAVI) Approach toward students' motivation in learning English.
\end{abstract}

Keywords: SAVI, model, improve, motivation, student

\section{INTRODUCTION}

The English main source which is the cause of the low motivation of student learning, some problems that are often encountered in the learning process more aspects indicates the teacher and students, materials of English lesson, grammar etc. The aspect of the teacher some of the problems are: The teacher has not been able to activate students in learning, the learning didn't focused on student activities, the teacher acts as a source of information so that students just listen, take notes and do exercises, beside that the student have problem in master of English, they can't memorize well more vocabulary and it meaning, student can't speaking, writing use well English grammar, their imagine English is very difficult lesson and they have lower motivation to learning English, the student have not more chance to practice English. It has more problems in teaching and learning English, the student need motivation to learn English well, motivation is very important. According to[1] motivation to describe those processes that can (a) arouses and instigate behavior, (b) give direction or purpose to behavior, (c) continue to allow behavior to persist, and (d) lead to choosing or preferring a particular behavior, [2] Motivation plays a role of a stone in individual's life that creates thrill in stagnant waters. [3] Declares motivation as a very important factor to achieve a goal. As like other fields of life foreign language learning also depends on motivation a lot. [4] Teachers need to appropriately plan to enable self-regulated learning, which is basically seen to 
empower the student to take their own direction, and evince internal motivation as they take control of the learning process. Self-regulation. [5] Whereas motivated students tend to engage in activities that they believe will help them learn, unmotivated students are not able to be systematic in making an effort in learning, as are motivated students.

The importance of motivation is often emphasized in the field of language. [6] English in Indonesia is very difficult because English is foreign language. The students need to think hard and even translate to catch the meaning from the target language to the second language. [7] Through the ages many approaches and methods have been implemented with the idea of improving the teaching and learning processes of English as a foreign language and the needs for which English is studied change through the time. [7] A lecturer should know about the condition of their students and make the students able to master the subject well. They also should know some problems that are faced by the students in studying English language and give them good understanding of English. [7] Motivation is present in every field where humans show progress such as language learning. When we examine major determinants in language acquisition, motivation appears among the most important ones. [7] motivation is willingness to do something without needing to be told or forced to do it, in other case motivation is the reason why someone to do something. [8] Observation and questionnaires would be used as instruments in order to acquire information regarding participants' background, which includes participants' identity, participants' prior Institute, participants' confidence in their English. One of the innovative learning models given it solation is the SAVI learning model.[8] Somatic, Auditory, Visual, and Intellectual (SAVI) is a method which involves all of the potentials in the body to study or all of sensory registers, this method was created by Meier (1999).

Somatic means learning by moving and doing, Auditory means learning by talking and hearing, Visual means learning by observing and picturing, and Intellectual means learning by problem solving and reflecting. If a study can entangle of all the elements of SAVI, the study will take place effectively and attractively, especially when it applied in reading activity. [8] "SAVI Approach" which stands for Somatic (learning by physical activity that uses the body in some way), Auditory (learning by talking and social interaction), Visual (learning by watching and listening ), Intellectual (learning by reflecting, thinking and analyzing).[8] Lecture must know the condition of their students and make the students able to master the subject well. They also should know some problems that are faced by the students in studying English language and give them good understanding of English. [9] is important thing that should be prepared well by the lecture in delivering the materials to the students. One of them that can support teaching learning process is the material. Good materials should be based on the students' need. It means the material that is given to the students must be appropriate to the context. Teaching [10] teacher must give the students chance to actively in learning process and to application the suitable of the approach for the student.

\section{Research Hypothesis}

Ha: There is a significant influence of using somatic auditory visual Intellectual (SAVI) approach towards students' motivation in English learning at the first semester of the PGSD in the academic year of 2016/2017.

Ho: There is no a significant influence of using somatic auditory visual Intellectual (SAVI) approach towards students' motivation in English learning at the first semester of the PGSD in the academic year of 2016/2017.

\section{RESEARCH METHODS}


The research methodology was experimental design with the treatment held in 3 meetings 40 minutes for each. In this research, the researcher took two classes, one class as the experimental class and one class as the control class. In the experimental class, used SAVI approach and in the control class the researcher didn't used SAVI approach. The population of research was the PGSD students of education faculty at State University of Makassar. The samples of this research were two classes consisting of students. In collecting the data, the researcher used instrument in the form questionnaire, observation, and pretest and posttest. The instrument was used for pre-test and post-test. After giving the post-test, the researcher analyzed the data by using SPSS.

\section{RESULTS AND DISCUSSION}

\subsection{RESULTS}

1. Overview of the Application of the SAVI Approach

a. Teacher Activity Observation Sheet

Table 4.1 Results of Observation on the Implementation of the Learning Process

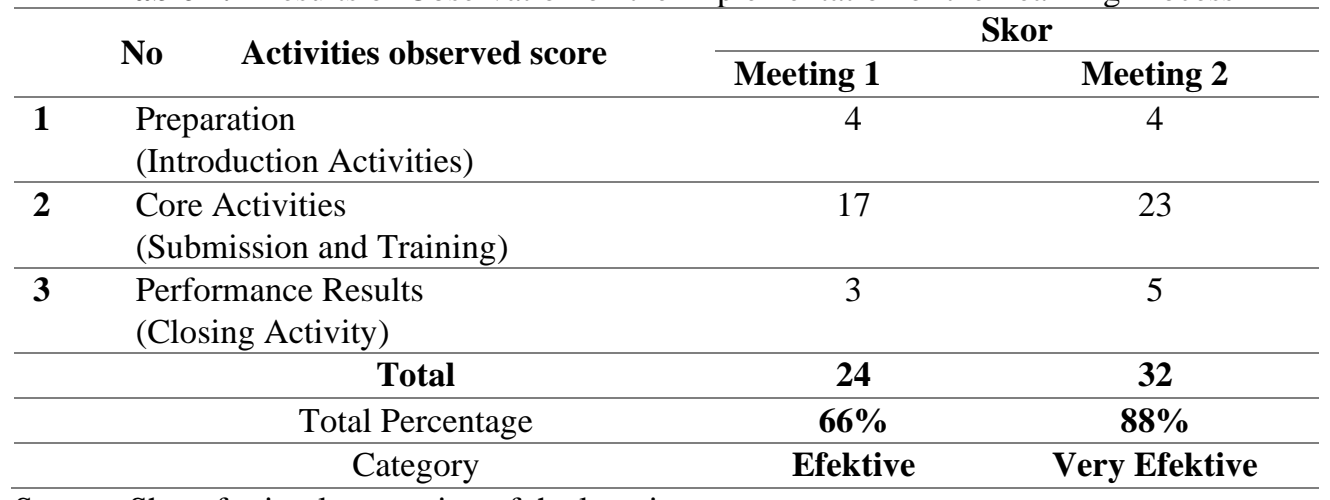

Source: Sheet for implementation of the learning process

Based on the data in the table it can be concluded that the learning process runs effectively at the first meeting with a presentation of $72 \%$. The data shows that the delivery of material using the SAVI is effective. While at the second meeting, the learning process very effectively compared to the previous meeting, this was indicated by the implementation of activities at almost every point which increased with a presentation of $88 \%$.

\section{b. Student Activity Observation Sheet}

Table 4.2. Description of Student Observation Sheet

\begin{tabular}{ccrr}
\hline \multirow{2}{*}{ No } & Aspects Observed Scores & \multicolumn{3}{c}{ Skor } \\
\cline { 3 - 4 } & & meeting 1 & meeting ke 2 \\
\hline $\mathbf{1}$ & Somatic & 6 & 8 \\
\hline $\mathbf{2}$ & Audiotory & 6 & 8 \\
\hline $\mathbf{3}$ & visualization & 7 & 8 \\
\hline $\mathbf{4}$ & intelectually & & 8 \\
\hline
\end{tabular}


Total

26

32

\begin{tabular}{ccc}
\hline Total percentage & $\mathbf{7 2 , 2 2} \%$ & $\mathbf{8 8 , 8 8 \%}$ \\
\hline Category & Efektif & Very Efektif \\
\hline Source: Data processed, 2019 (Appendix III) & &
\end{tabular}

Based on these data it can be concluded that at the first meeting the learning process was carried out with a percentage of achievement level of $72.22 \%$ and was in the effective category. At the second meeting the learning process with a percentage of achievement level of $88.88 \%$ and was in the very effective category. The percentage of achievement is obtained from two meetings by dividing the score the indicator achieved with a maximum score multiplied by $100 \%$. This shows that the implementation of learning using the SAVI learning model conducted by students for each meeting increases.

\section{Overview of Student Learning Motivation in Science Learning}

a. Data on pretest students about science learning motivation in the experimental and control classes

Table 4.5 Qualifications and Pretest Intervals of Control Class Students

\begin{tabular}{|c|c|c|c|c|c|}
\hline $\begin{array}{l}\text { Interval } \\
\text { Value }\end{array}$ & Mean & Qualification & category & Frequency & $\begin{array}{l}\text { Cumulative } \\
\text { Percentage }\end{array}$ \\
\hline $75-100$ & \multirow{3}{*}{73,96} & Height & \multirow{3}{*}{ Medium } & 9 & $34,61 \%$ \\
\hline $50-74$ & & Medium & & 17 & $65,38 \%$ \\
\hline $25-49$ & & Low & & & \\
\hline
\end{tabular}

Based on table 4.5, The science learning motivation of students in the control class are 9 students $(34.61 \%)$, in the high category and 17 students $(65.38 \%)$ in the moderate category.

Table 4.7 Qualifications and Pretest Intervals of Experimental class students

\begin{tabular}{|c|c|c|c|c|c|}
\hline $\begin{array}{c}\text { Interval } \\
\text { Value }\end{array}$ & Mean & Qualification & category & Frequency & $\begin{array}{l}\text { Cumulative } \\
\text { Percentage }\end{array}$ \\
\hline $75-100$ & \multirow{3}{*}{74,81} & Height & \multirow{3}{*}{ Medium } & 8 & $30,76 \%$ \\
\hline $50-74$ & & Medium & & 18 & $69,23 \%$ \\
\hline $25-49$ & & Low & & & \\
\hline
\end{tabular}

Based on table 4.7 , it can be concluded that the results of science learning motivation of students in the control class are 8 students $(30.76 \%)$, in the high category and 18 students $(69.23 \%)$ in the medium category.

b. Student Posttest Data on Science Learning Motivation Experiment and Control Classes

Table 4.10 Qualifications and Posttest Intervals of Control Class students 


\begin{tabular}{|c|c|c|c|c|c|}
\hline $\begin{array}{c}\text { Interval } \\
\text { Value }\end{array}$ & Mean & Qualification & category & Frequency & $\begin{array}{l}\text { Cumulative } \\
\text { Percentage }\end{array}$ \\
\hline $75-100$ & \multirow{3}{*}{74,42} & Height & \multirow{3}{*}{ Height } & 10 & $30,76 \%$ \\
\hline 50-74 & & Medium & & 16 & $69,23 \%$ \\
\hline $25-49$ & & Low & & & \\
\hline
\end{tabular}

Based on table 4.10, it can be concluded that the results of students' learning motivation in the control class are 10 students $(38.46 \%)$, in the high category and 16 students $(61.53 \%)$ in the medium category.

Table 4.12 Qualifications and Posttest Intervals of Experimental class students

\begin{tabular}{|c|c|c|c|c|c|}
\hline $\begin{array}{c}\text { Interval } \\
\text { Value }\end{array}$ & Mean & Qualification & category & Frequency & $\begin{array}{l}\text { Cu,ulative } \\
\text { Percentage }\end{array}$ \\
\hline $75-100$ & \multirow{3}{*}{$88,38 \%$} & Height & \multirow{3}{*}{ High } & 3 & $11,53 \%$ \\
\hline $50-74$ & & Medium & & 23 & $88,46 \%$ \\
\hline $25-49$ & & Low & & & \\
\hline
\end{tabular}

Based on table 4.12, it can be concluded that the results of science learning motivation of students in the control class are 3 students $(11.53 \%)$, in the high category and 23 students $(88.46 \%)$ in the moderate category.

\section{Effect of the SAVI approach on English Learning Motivation Students}

\section{Test Data Analysis Assumptions}

The results of inferential statistical analysis are intended to answer the hypotheses that have been formulated.

\section{1) Normality Test}

Table 4.13. Normality Test Results and Pretest and Posttest Data of Experimental Classes and Control Class

\begin{tabular}{lcc}
\multicolumn{1}{c}{ Data } & Probability Value & Keterangan \\
\hline Pretest Class Experiments & 0,200 & $0,200>0,05=$ normal \\
\hline Pretest Control Class & 0,200 & $0,200>0,05=$ normal \\
\hline Posttest Class Experiment & 0,200 & $0,200>0,05=$ normal \\
\hline Posttest Control Class & 0,113 & $0,113>0,05=$ normal \\
\hline
\end{tabular}

Source: IBM SPSS Statistic Version 20

Based on these data indicate that the data the pretest and posttest experimental class and control class are normally distributed, the normality test on the four data where a probability 
value greater than 0.05 is obtained so that the experimental class and control class data are normally distributed.

\section{1) Homogeneity Test}

Table 4.14. Pretest and Posttest Homogeneity Test Results for Experimental and Class Classes Control

\begin{tabular}{lcc}
\hline \multicolumn{1}{c}{ Data } & $\begin{array}{c}\text { Probability } \\
\text { Value }\end{array}$ & Keterangan \\
\hline $\begin{array}{l}\text { Pretest } \text { of experimental class and control } \\
\text { class }\end{array}$ & 0,601 & $\begin{array}{l}0,601>0,05= \\
\text { homogeneous }\end{array}$ \\
\hline $\begin{array}{l}\text { Posttest of experimental class and } \\
\text { control class }\end{array}$ & 0,856 & $\begin{array}{l}0,856>0,05= \\
\text { homogeneous }\end{array}$ \\
\hline
\end{tabular}

\section{Source: IBM SPSS Statistic Version 20}

Based on these data of table 4.14 shows that the results of the homogeneity test of the experimental class pretest and the control class and the posttest of the experimental class and the control class in homogeneous so that the probability value is greater than 0.05 . After obtaining the homogeneity test results of the experimental class and the control class,.

\section{a. Hypothesis testing}

\section{1) Pretest Independent Sample T-Test Experiment Class and Control Class}

As for the results of the independent sample t-test the value of the pretest of the experimental class and the control class as follows.

Table 4.15. Independent Sample T-Test Pretest Experiments and Pretest ControlsT Data Df Probability Value Description

\begin{tabular}{|c|c|c|c|c|}
\hline Data & $\mathbf{T}$ & Df & $\begin{array}{c}\text { Nilai } \\
\text { Probabilitas } \\
\end{array}$ & Keterangan \\
\hline $\begin{array}{l}\text { Pretest Class Experiments and } \\
\text { Pretest Control Class }\end{array}$ & 0,544 & 50 & 0,589 & $\begin{array}{c}0,589>0,05=\mathrm{No} \\
\text { Difference }\end{array}$ \\
\hline
\end{tabular}

Source: IBM SPSS Statistic Version 22

Based on the table, information can be obtained that the probability value is $0.589>0.05$ and the value of $\mathrm{t}$ is equal to 0.554 with the value of $\mathrm{t}$ table 2.008 obtained through the table by looking at the value $\alpha=5 \%$ and $\mathrm{df}=50$, then $\mathrm{t}$ count has a value smaller than table $(0.544$ $<2.008$ ) and probability value $0.589>0.05$ Thus it can be concluded that $t$ count $<t$ table shows that the pretest data obtained is not significantly difference.

\section{2) Calculating N-Gain}

Table 4.16. Pretest N-gain and Posttest Results of Experimental Classes and Control Classes

\begin{tabular}{cllcll}
\hline & grup & $\mathbf{N}$ & Mean & $\begin{array}{l}\text { Std } \\
\text { Deviation }\end{array}$ & $\begin{array}{l}\text { Std. Error } \\
\text { Mean }\end{array}$ \\
\hline \multirow{2}{*}{ Gain } & Eksperiment & 26 & 8,5385 & 7,83444 & 1,53646 \\
\cline { 2 - 6 } & Control & 26 & 5,5769 & 6,73007 & 1,31988 \\
\hline
\end{tabular}


Source: IBM SPSS Statistic Version 22 (Appendix VII)

The experimental group $(\mathrm{M}=8.5385)$ has a higher change than the control group $(\mathrm{M}=$ 5.5769 ) it show that larger changes occur in the experimental group

3) Independent Sample T-Test Posttest Experiment Class and Control Class

Table 4.17. Independent Sample T-Test Posttest Experiments and Control Posttest

\begin{tabular}{|c|c|c|c|c|c|}
\hline Data & & $\mathbf{T}$ & df & Probability Value & Keterangan \\
\hline $\begin{array}{l}\text { Posttest Eksperiment } \\
\text { Posttest control classes }\end{array}$ & class & 2,336 & 50 & 0,024 & $\begin{array}{l}0,024<0,05=\text { There } \\
\text { Are Differences }\end{array}$ \\
\hline
\end{tabular}

The table 1.17 show that the probability value is smaller than 0.05 . This shows that there is a significant difference between students' learning motivation between classes who in learning using the SAVI approach and the class that follows learning without using the SAVI learning. The value of $t$ count is 2,336 compared to the value of $t$ table of 2,008 by looking at the value of $\alpha=5 \%$ and $\mathrm{df}=50$, then $\mathrm{t}$ count has a value greater than $\mathrm{t}$ table $(2,336>2,008)$. Thus it can be concluded that $t$ count $>t$ table, this means that the posttest data obtained shows there are significant differences.

\section{DISCUSSION}

The learning process in the experimental class uses an observation sheet to observe the activities of teachers and students in order to obtain an overview of the SAVI learning approach. Assessments for teachers are assessed from several aspects, namely preparation activities, core activities and performance outcomes (closing activities). At the first meeting, the learning process using the SAVI learning approach was quite effective. The second meeting, the learning process is classified as very effective. The lecture's activities using the SAVI have improved. Observation of student activities includes several aspects, namely somatic, auditory, visual, intellectual which consists of several indicators.

The results of the calculation of student learning motivation for the experimental class before being given treatment (pretest) is in the medium category and for the control class is in the category of the medium category. Furthermore, the results of the calculation of student learning motivation scores for the experimental and control classes after being given treatment. In the experimental class is in the high category, then for the learning motivation control class is in the medium category.

Based on hypothesis testing with inferential statistics shows that there is a significant effect on student learning motivation after the use of the SAVI learning model in the learning process. The results of hypothesis testing are carried out in two ways, namely comparing table and t-count and comparing probability values. Statistical results using manual calculations for the independent sample t-test combined with the help of the SPSS 22 program obtained the value of $\mathrm{t}$ table with $\mathrm{df}(50)=2,008$, while the t-test for student learning motivation was 2,336. This means that $\mathrm{t}$ count $(2,336)>\mathrm{t}$ table $(2,008)$ so that $\mathrm{H} 0$ is rejected and $\mathrm{Ha}$ is accepted. Whereas by comparing the probability values obtained the significance value of student learning motivation (posttest) experimental class and control class is 0.025 . This means that $t$ count $>\mathrm{t}$ table so that $\mathrm{H} 0$ is rejected and $\mathrm{Ha}$ is accepted. 


\section{Conclusion}

Based on the results of the research conducted, it can be concluded several things, among others: The implementation of learning using the SAVI learning model is carried out in accordance with the stages that the teacher should be in the effective category and for the second is in the very effective category. Whereas for the observation results of the first meeting students are in the effective category and the second is in the very effective category, the motivation for student learning in the experimental class is more than the students' motivation in the control class. This is evidenced by the posttest value in the experimental class in the high category, while in the control class is in the moderate category, There is the influence of the application of the SAVI learning model .

\section{Suggestion}

The suggestions that can be given by researchers to several parties are as follows: For teachers, in order to routinely apply SAVI learning so students are motivated in learning supported by the use of models and learning media that are active and fun, Student enthusiasm depends on learning motivation embedded in him, For that the teacher must be the best motivator for each of his students. For other researchers, this study is limited in looking at the number of variables and populations so it is advisable to conduct broader research to expand the results of the study

\section{BIBLIOGRAPHYI}

[1] T. Takahashi, "Motivation of students for learning English in Rwandan schools," vol. 28, no. 1, pp. 168-186, 2018.

[2] D. Fkip and U. Gresik, "USING INTERACTIVE VIDEO TO IMPROVE STUDENTS MOTIVATION IN LEARNING ENGLISH By: ULFATUL MA , RIFAH RIRIS IKA WULANDARI," pp. 81-87.

[3] F. Xiao, "Motivational Strategies in Teaching English as Foreign Language------Applying Motivation plan in TEFL," vol. 3, no. 18, pp. 257-262, 2013.

[4] M. A. Saleem and M. Ghani, "The Role of Motivational Teaching Strategies Used by English Language Teachers in Urdu Medium Secondary Schools in Pakistan," vol. 9, no. 2, pp. 343-352, 2019.

[5] H. G. Valencia, "The Integration of Native Language in EFL Classes," vol. 12, no. 1, pp. 1-6, 2019.

[6] S. A. Ahmed and M. A. Dakhiel, "Effectiveness of Learner-Centered Teaching in Modifying Attitude Towards EFL and Developing Academic Self-Motivation Among the 12th Grade Students," vol. 12, no. 4, pp. 139-148, 2019.

[7] I. Tosuncuoglu, "The Interconnection of Motivation and Self Regulated Learning Among University Level EFL Students," vol. 12, no. 4, pp. 105-114, 2019.

[8] F. Yuniarti, "TEACHING LISTENING ABILITY BY USING SOMATIC , AUDITORY, VISUAL , AND INTELECTUAL ( SAVI ) TECHNIQUE,” vol. 4, no. 2, pp. 142-154, 2018.

[9] F. Yuniarti, "TEACHING LISTENING ABILITY BY USING SOMATIC , AUDITORY, VISUAL, AND INTELECTUAL ( SAVI ) TECHNIQUE,” vol. 4, no. 2, pp. 143-155, 2018. 
[10] R. Y. Andrianti, R. Irawati, and A. Sudin, "PENGARUH PENDEKATAN SAVI ( SOMATIC , AUDITORY , VISUAL , INTELLECTUAL ) DALAM MENINGKATKAN KEMAMPUAN KOMUNIKASI MATEMATIS DAN MOTIVASI BELAJAR SISWA SEKOLAH DASAR PADA MATERI PENGOLAHAN DATA," vol. 1, no. 1, pp. 471-480, 2016. 